\title{
Determinants of Compliance with AAOIFI Standards by Islamic Banks
}

\author{
Sherif El-Halaby \\ Plymouth University \\ Khaled Hussainey \\ Plymouth University
}

Purpose: We explore the level and determinants of compliance with Accounting and Auditing Organisation for Islamic Financial Institutions (AAOIFI) financial and governance standards by Islamic banks (IBs).

Methodology: Our sample consists of 43 IBs across 8 countries. We use ordinary least squares regression analyses to examine the impact of Bank-specific characteristics and corporate governance mechanisms concerned with Board of Directors (BOD) and Sharia Supervisory Board (SSB) on levels of compliance with AAOIFI standards.

Findings: We find that the average compliance level based on AAOIFI standards concerning the Sharia Supervisory Board Report (SSBR) is 68\%; corporate social responsibility report (CSRR) is $27 \%$ and presentation of financial statements (FS) is $73 \%$. The aggregate disclosure based on the 3 indices is $56 \%$. The analysis also shows that size, existing Sharia auditing department, age, and corporate governance of SSB are the main determinants of compliance levels.

Originality: he determinants of compliance with AAOIFI standards for IBs around the world not been explored before and, therefore, this paper is the first of its kind to this issue.

\section{Introduction}

We examine the determinants of compliance with Accounting and Auditing Organization for Islamic Financial Institutions (AAOIFI) standards by Islamic Banks (IBs).

The literature on compliance with AAOIFI explores the compliance level (e.g., Ullah, 2013; Vinnicombe, 2010; Ahmed and Khatun, 2013). However, the determinants of the compliance, considering both firm characteristics and board and Sharia Supervisory Board (SSB) characteristics, have not yet been empirically investigated. Our paper fills the research gap. Furthermore, majority of prior research focuses on a single country (e.g., Hafij, 2013; Ahmed and Khatun, 2013), or is restricted to one category of AAOIFI standards such as the presentation of financial statements (Hafij, 2013) or Corporate Social Responsibility (CSR) (Hassan and Harahap, 2010).

We contribute to existing literature in a number of ways. First, we consider majority of IBs that adopt AAOIFI. Secondly we consider three AAOIFI standards related to Sharia, social and 
financial disclosures. Thirdly, we are the first large scale study that explores IBs' compliance with AAOIFI standards after 2010 (the updated version for AAOIFI which includes new financial and governance standards). Finally, we are the first to examine the impact of both country (i.e. culture) and bank characteristics on compliance with AAOIFI standards.

Our results indicate that the compliance level with AAOIFI Governance Standard No.1 is 68\%; the compliance level with AAOIFI Governance Standard No.7 is $27 \%$ and compliance level with AAOIFI accounting Standard No.1 is $73 \%$. The empirical analysis shows that size; age; SAD (Sharia Auditing Department); UA (uncertainty avoidance) and corporate governance of SSB (Sharia Supervisory Board) is significantly associated with levels of disclosure.

Our paper is organised as follows: Section 2 discusses issues related to compliance with AAOIFI standards. Section 3 reviews the literature and develops the hypotheses. Section 4 discusses the methodology. Section 5 discusses the descriptive analysis. Section 6 reports the findings. In section 7, we discuss our findings. Section 8 concludes.

\section{Compliance with AAOIFI}

AAOIFI formulates and issues accounting, auditing, governance, ethics and Sharia standards for IFIs. AAOIFI as an independent international organisation, is supported by institutional members (200 members from 40 countries) including central banks, IFIs, and other participants from the international Islamic banking and finance industry worldwide (AAOIFI, 2015). Currently, AAOIFI has published 88 standards including 26 accounting standards, 5 auditing standards, 7 governance standards, 2 ethics standards, and 48 Sharia standards (AAOIFI, 2015). For the purpose of this study, compliance can be defined as "the degree to which IBs comply with the multitude of issues in the accounting and governance standards issued by the AAOIFP". The following section explores the three AAOIFI standards of interest.

\subsection{AAOIFI and SSB}

According to AAOIFI, a Sharia Supervisory Board (SSB) is defined as "an independent body of specialised jurists in figh al mu'amalat (Islamic commercial jurisprudence)" (AAOIFI, 2010). The purpose is to ensure IFIs are in compliance with Sharia principles. AAOIFI published Governance Standard No.1, which specifies the composition of the board, and the basic elements of its annual report.

\subsection{AAOIFI and CSR}

Corporate social responsibility (CSR) for IFIs refers to "all activities carried out by an IFI to fulfil its religious, economic, legal, ethical and discretionary responsibilities as financial intermediaries for individuals and institutions" (AAOIFI, 2010). AAOIFI issued Governance Standard No.7 in 2010 to organise the activities related to CSR. The primary objective for this standard is to ensure that CSR activities and compliance of IFIs are communicated in a truthful, transparent and comprehensible manner to relevant stakeholders (AAOIFI, 2010). The accountability for disclosure under this standard is divided between mandatory disclosure (such as earnings and expenditure prohibited by Sharia and Zakat) and recommended disclosure (such as Qard Hasan, charitable activities and Waqf management) (AAOIFI, 2010).

\subsection{AAOIFI and the presentation and disclosure in the financial statements}

In 1993, AAOIFI issued Accounting Standard No.1 related to general presentation and disclosure in the financial statements of IBs. "The objectives of financial reports is to provide information 
about the IFI's compliance with Islamic Sharia; information about IFI's economic resources and related obligations; information to assist in the determination of Zakat; IFI's discharge of its fiduciary and social accountabilities" (AAOIFI, 2010). Based on this standard, the annual report contains 7 basic statements in addition to basic information about the bank, significant accounting policies and other information.

\section{Relevant literature and hypotheses development}

We use both agency and signalling theories to identify the potential drivers of compliance with AAOIFI standards.

\subsection{Firm-specific characteristics}

\subsubsection{Auditor}

Auditors play an important role in the credibility of firms' financial information (Healy and Palepu, 2001). Chalmers and Godfrey (2004) stated that to maintain their reputation and avoid reputation costs, high-profile auditing companies are more likely to demand high levels of disclosure. The signalling theory suggests that the choice of an external auditor can serve as a signal of firm value. Generally, companies signal the quality of their financial reports by choosing large audit firms (Datar et al., 1991). This expectation is consistent with agency theory which holds that larger audit firms have a stronger incentive to impose more extensive disclosure standards because they have more to lose from damage to their reputations. The findings of Xiao et al. (2004) supported this proposition with a positive relationship between firms employing one of the Big 4 international auditing firms and their scopes of corporate disclosure. Guerreiro et al., (2008); Hodgdon et al. (2009) examined corporate disclosure and found it to be positively related to auditor size. Therefore, we hypothesize that:

H1. The degree of disclosure is predicted to be higher in IBs audited by the Big 4 auditors than in IBs that are audited by non-Big 4 auditors

\subsubsection{Age of bank}

Older, well-established companies are likely to disclose much more information in their annual reports than younger companies because they are less likely to suffer any competitive disadvantage. In addition, the cost and the ease of gathering, processing, and disseminating the required information may be a contributory factor (Owusu-Ansah, 1998). Many studies have shown that disclosure level is positively associated with company age (Cormier et al., 2005; Hossain and Hammami, 2009) while others (Alsaeed, 2005) conclude that the age of the corporation has insignificant association with the level of disclosure. Therefore, we hypothesize that:

\section{H2: Older IBs are expected to disclose more information than younger IBs}

\subsubsection{Firm size}

According to agency theory, larger firms need to disclose more information to different user groups which leads to a decline in agency costs and reduces information asymmetries (Inchausti, 1997). In prior disclosure studies, the association between firm size and disclosure reporting is mixed. For example, while some studies found a positive association (Hassan et al., 2006; Elshandidy et al., 2013), others found an insignificant association (Rajab and Schachler, 2009). Firm size is a significant determinant of disclosure and accounting policy choice" and a "discriminator for accounting quality (Rahman et al., 2002). Moreover, large firms face higher 
demand for information from customers, analysts and the general public (Cooke, 1989). This results in increased pressure to disclose information. Therefore, we hypothesize that:

\section{H3. Large IBs are more likely to disclose more information than small IBs}

\subsubsection{Profitability}

Inchausti (1997) suggested that profitability is capable of influencing the extent to which companies disclose information items. Consistent with the signalling theory, management when in possession of "good news" due to better performance are more likely to disclose more detailed information to the stock market than that provided by companies in possession of "bad news" to avoid undervaluation of their shares. Ahmed and Courtis (1999) showed that the results of prior studies provide mixed evidence on the association between firm's profitability and the level of corporate disclosure. Elshandidy et al. (2013) reported a positive association between both variables. Nonetheless, agency theory expects that managers of firms with high profitability would tend to provide more corporate information to justify their present performance to the shareholders.

Therefore, we hypothesize that:

\section{H4. Disclosure are expected to be higher for highly profitable IBs than low profit}

\subsubsection{Internal Sharia auditing department (ISAD)}

Mercer (2004) argued that the Sharia auditing department "serve as the first line of defence against disclosure errors, ferreting out unintentional errors caused by weaknesses in a company's internal controls and intentional errors due to fraud'. The internal audit function plays a unique and critical role in corporate governance by helping to ensure the reliability of financial reporting (Gramling et al., 2004; Carcello et al., 2005). The literature provides evidence that internal auditing has positive impact on financial reporting oversight and level of disclosure. Schneider and Wilner (1990) found that the presence of internal auditors deters fraudulent financial reporting. Other studies establish links between internal auditing and firm performance (e.g., Gordon and Smith, 1992). Archambeault et al. (2008) highlighted the need for an internal audit to improve governance transparency. Wilson and Walsh (1996) provided a basis for predicting that an internal auditing department will increase investors' confidence in financial reporting reliability and perceived oversight effectiveness. Therefore, we hypothesize that:

H5: The level of corporate disclosure is positively associated with ISAD inside IBs

\subsection{Corporate Governance (CG) of BOD characteristics}

To develop our research hypotheses, we review prior research which suggests an association between corporate disclosure and certain corporate governance mechanisms (La Porta et al., 2002; Eng and Mak, 2003).

\subsubsection{Number of block holders}

A block holder is a shareholder with an exceptionally large amount of shares. Early research indicated a negative relation between block holder ownership and disclosure (Schadewitz and Blevins, 1998; Hossain et al., 1994), while Haniffa and Cooke (2002) found a positive association. Marston and Polei (2004) argued that investors who own a large proportion of equity shares in a company can obtain information about the company from internal sources. Therefore, more 
closely held companies are more likely to disclose less information because their large investors can access internal sources of information. Therefore, we hypothesize that:

\section{H6. IBs with high percentages of block holder ownership have low levels of disclosures}

\subsubsection{Institutional ownership}

Agency theory predicts that ownership structure affects the level of corporate disclosure (Eng and Mak, 2003). The relationship between institutional ownership and disclosure has been examined in prior studies; however, the empirical evidence is mixed. Schadewitz and Blevins (1998) found a negative association, while Mangena and Pike (2005) found a positive association between the two variables. IBs with a concentrated ownership structure do not have to disseminate more corporate information, because the main shareholders can easily obtain it, as they usually have access to that information. Therefore, we hypothesize that:

\section{H7. There is a negative relationship between disclosure and institutional ownership}

\subsubsection{Foreign ownership}

Based on agency theory, Fama and Jensen (1983) suggested that as the number of shareholders increases and ownership becomes more dispersed, the demands for additional information increase. Recent studies have found an association between disclosure and foreign ownership. For instance, according to Xiao et al. (2004), higher foreign ownership not only encourages information disclosure, but also motivates firms to create English web pages to facilitate dissemination of financial information. The extent of foreign investor ownership is an important determinant of the demand for financial information (Soderstrom and Sun, 2007). Therefore, we hypothesize that:

\section{H8. There is a positive relationship between disclosure for IBs and foreign ownership.}

\subsubsection{Duality in position}

Role duality in position exists when the CEO (chief executive officer) is also the chairman of the board. Agency theory predicts that role duality creates individual power for the CEO that would affect the effective control exercised by the board. Fama and Jensen (1983) argue that independent directors can play a significant role in monitoring the performance of managers. The results of prior research provide mixed evidence on the association between duality in position and corporate disclosure. Some studies find a negative association between the two variables (Laksmana, 2008; Gul and Leung, 2004). Other studies did not find any significant association (Cheng and Courtenay, 2006). Therefore, we hypothesize that:

\section{H9. IBs with duality in position have a lower level of corporate disclosures.}

\subsubsection{Board independence}

Fama (1980) argued that the board of directors, which is elected by the shareholders, is the central internal control mechanism for monitoring managers. Chau and Leung (2006) suggested that independent directors will increase the quality of monitoring over management, because "they are not affiliated with the company as officers or employees, and thus are independent representatives of the shareholders' interests" (Pincus et al., 1989, p.246). The presence of independent directors on boards may improve the quality of financial statements (Peasnell et al., 2005). Prior research supported 
the positive association between disclosure and board independence (i.e. Chen and Jaggi, 2000). Therefore, we hypothesize that:

H10. IBs with higher proportions of independent non-executive directors on the board have higher levels of corporate disclosures.

\subsection{Corporate Governance of SSB Characteristics}

In the context of Islam, the model of corporate governance for business organisations is derived from the Sharia rulings. For example, they have to design the system according to Sharia principles and provide stakeholders' rights protection (Hassan, 2008). According to Grais and Pellegrini (2006), the unique attributes of IBs must be clarified in order to improve corporate governance mechanisms. Therefore, SSB is the most important distinction between Islamic banks and conventional banks (Farook et al., 2011; Grais and Pellegrini, 2006). Previous studies have found that the existence of the SSB and its characteristics have increased the disclosure levels of IBs (Farook et al., 2011).

\subsubsection{SSB size}

Empirical evidence suggested that board size can affect the level of disclosure (Akhatruddin et al., 2009). The common number of SSB members in IBs is between three and five members based on AAOIFI Governance Standard No.7. According to Chen and Jaggi (2000), a larger board size may decrease the possibility of information asymmetry. Agency theory predicts that larger boards incorporate a variety of expertise which results in more effectiveness in the monitoring role of the boards (Singh et al., 2004). Moreover, a higher number of board members may also reduce the uncertainty and the lack of information (Birnbaum, 1984). The board's size is likely to affect its ability to control and review all transactions to ensure their operations. With more members, the collective knowledge and experience of SSB will increase, and lead to greater disclosure. Therefore, we hypothesize that:

H11: There is a positive relationship between size of SSB and disclosure levels

\subsubsection{SSB Cross-memberships}

Cross-memberships of SSB members may also influence the corporate disclosure of IBs (Farook et al., 2011). There is evidence that cross-directorships increase information transparency through comparing the knowledge that is gained from other companies (Dahya et al., 1996); and because decisions taken at one board may become part of the information for decisions at other boards (Haat et al., 2008; Haniffa and Cooke, 2002). The cross-membership of SSB members is preferable because of their ensuing knowledge and credibility (Lorsch and MacIver, 1989). Furthermore, SSB members with cross-memberships will be able to adopt their tacit and explicit knowledge into their application of Sharia rulings in Islamic banking. Therefore, we hypothesize that:

H12: There is a positive relationship between SSB cross-membership and disclosure

\subsubsection{SSB Reputation}


An SSB is composed of Sharia scholars who have wide knowledge of Islamic commercial law, but less experience of secular educational institutions. Hussain and Mallin (2003) showed that the determinants affecting the directors' appointments in Bahraini banks are pertinent skills, business practice and reputation. Sharia scholars have an excellent reputation in their community because of their universal knowledge of Islam and their credibility and significant role in that community. For this reason, reputation can be used as a measure for business knowledge, and therefore, scholars who have a good reputation will be able to comprehend better the modern applications of the banking industry pertaining to disclosure. Farook et al. (2011) indicated that reputation is instrumental in measuring the disclosure level among IBs. The reputation of an SSB is measured based on SSB membership on AAOIFI committees which is similar methodology of Farook et al. (2011). Therefore, we hypothesize that:

\section{H13: There is a positive relationship between SSB reputation and disclosure levels}

\subsection{Culture (AU)}

When scholars compare the disclosure practice of firms from diverse countries, they should consider country systems. A spacious amount of literature (e.g., Hope, 2003) has been conducted on determinants that might explain differences in accounting practices. Among the many factors studied, cultural values is claimed to be most essential. The national culture is an institutional factor that influences both managers' choices and investors' preferences regarding financial reporting (Hope, 2003). Hofstede (2001) proposed six culture dimensions which are widely used in accounting research ${ }^{1}$ (e.g., Doupnik and Tsakumis, 2004). Jaggi and Low (2000) argued that the cultural factors of a country have an indirect impact on financial disclosures. Wong (2012) suggested that uncertainty avoidance (UA) is the most influential cultural dimension that may affect disclosure. Therefore, in this research; we just added UA in our model to see for what extent it has impacts on the disclosure level. This consists with prior research that used only this dimension (e.g., Khlif and Hussainey, 2014). Gray (1988) argued that: The higher a country ranks in terms of uncertainty avoidance are more likely it is to rank highly in terms of secrecy or rank lower in terms of disclosure. Therefore, we hypothesize that:

H14: There is a negative association between uncertainty avoidance and disclosure

\section{Research methodology}

\subsection{Sample selection}

We choose all fully flagged IBs that adopted AAOIFI. Based on AAOIFI (2015), there are 141 associated members, but not all of these banks adopt AAOIFI. We choose banks that adopted AAOIFI in MENA countries (i.e. Bahrain, Yemen, Qatar, Syria, Palestine, Sudan, Oman, and Jordan). The analysis was limited to 2013 because we did not find significant differences between last 3 years (2011-2013).

\subsection{Construction of disclosure indices for assessing the validity and reliability}

We construct Sharia, Social and Financial indices based on AAOIFI standards as follows. First, we adopt the disclosure requirements of AAOIFI Governance Standard No.1, Accounting Standard

\footnotetext{
${ }^{1}$ Hofstede six dimensions are power distance (PD), uncertainty avoidance (UA), individualism (IND), masculinity (MAS), long-term orientation (LTO) and Indulgence (INDU).
} 
No.1, and Governance Standard No.7. We review the last available editions for AAOIFI (2010 and 2014). Second, we reviewed the literature that explores CSR, SSB and FS (e.g., Aribi and Gao, 2012; Maali et al., 2006; Haniffa and Hudaib, 2007; Hassan and Harahap, 2010; Belal et al., 2014; Ahmed and Khatun, 2013). This enables us to construct an initial index which includes 218 items required by AAOIFI standards. Then, to ensure the content validity of the index, it is reviewed independently by three other researchers. After receiving their comments and suggestions, any remaining ambiguities were discussed with a fourth experienced academic. The final index included 214 items as shown in Table 1. To ensure the reliability of the research instrument, the principal author and two independent researchers scored five randomly selected banks. Then, the findings of the three researchers were compared. Given that the final research instrument had been agreed by all investigators, differences in the compliance scores across the investigators were not significant. Based on this, one overall index and three sub-indices (Sharia, social and financial) were constructed. The scores for the overall index and sub-indices were calculated by assigning equal weightings to each item of disclosure, and the indices were derived by computing the ratio of actual scores awarded to the maximum possible score attainable for items that were applicable to each Islamic bank.

\section{[Insert Table 1 here]}

\subsection{Model specification and variable measurement}

We use Ordinary Least Squares (OLS) where the dependent variable is compliance/disclosure score and the independent variables include the factors discussed above. Therefore, we use the following OLS transformed multiple regression model:

\section{Disc $i=\beta 0+\beta 1 A U D+\beta 2 A G E+\beta 3 S I Z E+\beta 4 P R O F+\beta 5 S A D+\beta 6 B L O C K+\beta 7$ $I N S T+\beta 8$ FORGN + $\beta 9 D U A L+\beta 10$ B.INDEP+ $\beta 11$ SSBSIZ + $\beta 12$ SSBREPU+ $\beta 13$ SSBCROSS $+\beta 14$ UNCER+ $\varepsilon$}

Where Disc is the compliance indices, which measures the level of compliance of SSBR, CSRR, $\mathrm{SF}$ and aggregate disclosure for Islamic bank $\mathrm{i} ; \beta 0$ is the intercept; $\beta 1 \ldots \ldots \beta 14$ are regression coefficients; $\varepsilon$ is error term. Variables definitions are shown in Table 2. The disclosure score for each index is calculated as a ratio of the total items disclosed to 15 (maximum score for Sharia) for model 1; 104 (maximum score for financial) for model 2; 95 (maximum score for social) for model 3 and 214 (maximum score for aggregate disclosure) for model 4.

\section{[Insert Table 2 here]}

\section{Results of Disclosure and Compliance Levels}

\subsection{Level of compliance by banks and countries}

Table 3 shows the compliance levels for each bank over 2013. It shows that Bahrain Islamic bank; Qatar first investment bank and Cham bank are the highest bank that complies with sharia disclosure. Jordan Islamic bank is the highest one that discloses information about CSR whereas a Qatar Islamic bank is highest bank related to financial disclosure.

In terms of the comparison between disclosures types in each country, table 4 shows the disclosure levels for each country by number of banks and percentage based on average disclosure. The table indicates that Jordan disclosed 65\%, which is more than Bahrain (56\%). This is perhaps surprising, 
since compliance with AAOIFI is mandatory for IBs in Bahrain. Sudan is the lowest country for compliance with AAOIFI (46\%). Bahrain has the highest number of banks that have adopted AAOIFI (15 IBs) not only because Bahrain is the host nation for the AAOIFI, but, it is a requirement of the Central Bank of Bahrain that all IFIs licensed must comply with AAOIFI (Vinnicombe, 2010).

\section{[Insert Table 3 here] \\ [Insert Table 4 here]}

\subsection{Compliance levels with AAOIFI standards}

Table 5 shows the compliance levels with AAOIFI Governance Standards No.1 5. It shows that the average compliance level for our selected banks is $68 \%$. The disclosure level concerning with SSB members is $70 \%$ whereas the disclosure level concerned with SSB reports is $66 \%$. Information about names of SSB has got the highest items $(95 \%)$ whereas $22 \%$ only from our sample report that they are comply with AAOIFI.

\section{[Insert Table 5 here]}

Table 6 shows the compliance level with AAOIFI Governance Standard No.7. It shows that the average compliance level for our selected banks is $27 \%$ which is beyond our expectations. The disclosure level related to universal-oriented CSR items is $30 \%$ while the disclosure level related to Islamic-oriented CSR items is $23 \%$. It also shows that screening and informing clients for compliance with Islamic principles has the highest score $(42 \%)$ and disclosure about Waqf management has the lowest score $(2 \%)$.

\section{[Insert Table 6 here]}

Table 7 shows the compliance level with AAOIFI Financial Standard No.1. It shows that the average compliance level is $73 \%$. The disclosure level for universal-oriented financial disclosure is $86 \%$. However, the disclosure level related to Sharia-oriented financial disclosure is $36 \%$. The table shows that the average disclosure level that is recommended by AAOIFI as well as IFRS and GAAP for universal financial statements (Financial Position Statement, Income Statement, Cash Flow Statement, Statement of Changes in the Owner's Equity) is 88\% but the disclosure level related to Sharia-oriented financial statements (Statement of Changes in Restricted Investments, Statement of Zakat, and Statement of Qard Hasan) is 33\%.

\section{[Insert Table 7 here]}

Table 8 summarises the information provided by the annual reports for our 43 selected banks and discloses information about the main Islamic services such as Murababa and Musharakah. It shows that Murababa is the most popular service provided by IBs in the MENA region (91\%) then, Mudaraba $79 \%$ and Ijara 70\%. Salam is the lowest service presented (12\%).

\section{[Insert Table 8 here]}

Table 9 shows the overall compliance levels for the 4 models based on disclosure related to universal and Sharia orientation. It shows that the levels of compliance related to Sharia accountability for SSBM and SSBR are mainly similar (70\% and 66\%). The compliance for universal CSR is $30 \%$ and for Sharia CSR items is $23 \%$. Also, the compliance related to financial information common to international standards like IFRS is $86 \%$ whereas financial disclosure 
related to Sharia items is $36 \%$. Finally, compliance levels for items related to universal orientation are higher than information related to Sharia requirements. This result shows low compliance and disclosure level for social reporting of IBs. This result is matching with Maali et al. (2006); Hassan and Harahap (2010) and Farook et al. (2011) that recommend the extent of CSRD by IBs falls far short of their expectation $(13.3 \% ; 38 \%$ and $16.8 \%$ respectively). Maali et al (2006) indicate that IBs are not completely fulfilling their social role in accordance with the prescriptions of Islam. Based on our result; we conclude that IBs are mainly shaped and focused on economic incentives more than social norms which consistent with Aggarwal and Yousef, (2000). Kuran (2006) maintains that IBs appear to seek profit as aggressively as conventional banks. He argues that it is even unrealistic to suppose IBs' activities as well CSRD to differ or be more socially accountable than conventional as they run in the equal global capitalistic situations.

\section{[Insert Table 9 here]}

\section{Empirical results}

\subsection{Descriptive analysis}

Table 10 reports the descriptive statistics. It shows that the average compliance level based on the AAOIFI standard for SSBR requirements is $68 \%$, the compliance level for CSR is $27 \%$, and the compliance level for financial accountability is $73 \%$. Finally, the overall compliance for our selected banks is $56 \%$. $65 \%$ of the selected banks are audited by the Big 4 firms namely: Ernst and Young, KPMG, PricewaterhouseCoopers, Deloitte Touche Tohmatsu, and 67\% of the banks have a Sharia Auditing Department (SAD). The average overall age of IBs is 19 years. The average board size is 4 members. $71 \%$ of SSB members have cross-membership with SSBs in other Islamic Banks (for example, Sheikh Abdul Sattar Abu Ghuddah is a member of the Sharia Supervisory Boards of more than 10 Islamic Banks). 50\% of our SSB members are also members of AAOIFI committees and $57 \%$ of our SSB are members in more than one Islamic bank (Cross membership). The average number of blockholders is 3, mean institutional ownership is $58 \%$ and the average foreign ownership is $63 \%$. The mean percentage of independent directors on the board is $49 \%$.

\section{[Insert Table 10 here]}

\subsection{Regression results}

Regression results are shown in Table 11. It shows the cross-sectional OLS regressions for the aggregated score of disclosures and three subcategories (SSB, CSR and FS). For the SSB score (model 1), we find that the coefficient estimates variables related to corporate governance of SSB are positive and significant at the 5\% level. This result supports hypotheses H11, H12 and H13 that IBs which have SSBs with more than 4 members, as well as SSB members who have crossmembership with SSBs in other Islamic Banks and IBs with SSB members who are also members of AAOIFI committees disclose more Sharia information in their annual reports and websites. Furthermore, the coefficient estimates on Sharia auditing departments (SADs) is positive and significant. This supports hypothesis H5. Concerning model 2, the table shows that CSR is positive and significant with SIZE of bank at the 5\% level. This result supports hypothesis H3. Furthermore, the coefficient estimate on AGE is positive and significant indicating that older IBs disclose more information about social activities, which supports hypothesis $\mathrm{H} 2$. For model 3, we find that the coefficient estimates on SIZE and SAD are positive and significant. Therefore, we partially accept hypotheses H3 and H5. Regarding aggregate compliance (model 4), we find 
significant positive association between overall compliance and SIZE, AGE and SSB SIZE at the 10\% level. Therefore, hypotheses H2, H3 and H11 are partially accepted. For culture, we find that UA has a negative association with Sharia as well as aggregate disclosure level at the $10 \%$ level (models 1 and 4). This result is consistent with Elshandidy et al., (2013) who found a negative association between UA and disclosure. These results therefore support the acceptance of H14.

\section{[Insert Table 11 here]}

\section{Discussion}

The insignificant associations between corporate disclosure and auditors are consistent with prior research (Barako et al., 2006; Owusu-Ansah, 1998; Hossain et al., 1995). Our analysis identifies a significant association between disclosure level and existing SAD. This finding is consistent with previous literature which presents $\mathrm{SAD}$ as one of the main determinants of compliance with AAOIFI and shows that the internal audit function can enhance the disclosure quality (Bailey et al., 2003; Gramling et al., 2004; Carcello et al., 2005). Bank age is positively correlated with compliance. Empirically, we confirm the findings of Cormier et al. (2005) and Hossain and Hammami (2009) who reported a positive relationship between company age and corporate disclosure. The significant associations between corporate disclosure and bank size are consistent with prior empirical studies which identified company size as a determinant of disclosure level (Ahmed and Courtis, 1999; Street and Gray, 2001). We found that profitability is not associated with disclosure level. This result supports the argument that providing full disclosure in any situation is important whether it is achieving a profit or not (Haniffa, 2002). Also, this result is consistent with the findings of other researchers who did not find association between profitability and disclosure (Aras et al., 2010).

The results do not support that CG attributes concerned with BOD have a significant effect on corporate disclosure. Based on our analysis, we found an insignificant link between duality in position and corporate disclosure. This result is supported by Ho and Wong (2001), Arcay and Vazquez (2005) and Cheng and Courtenay (2006). Related to institutional ownership, our outcome is consistent with Eng and Mak (2003) who found an insignificant relationship between the two variables. Our paper concludes an insignificant association between compliance levels and board independence which is consistent with Haniffa and Cooke (2002) and Ho and Wong (2001) who did not find a relationship between the two variables. We find that the coefficient estimates on block holders and foreign ownership have an insignificant association with corporate disclosure. The insignificant sign on the number of block holders is consistent with the research of Samaha and Dahawy (2011) who did not find association between the variables. The insignificant link between foreign ownership and disclosure is consistent with Mangena and Tauringana (2007).

The significant associations between disclosure and CG variables concerned with SSB are consistent with prior empirical disclosure reporting research (e.g., Singh et al., 2004; Abdul Rahman and Bukair, 2013; Hussain and Mallin, 2003, Farook et al., 2011; Haat et al., 2008; Haniffa and Cooke, 2002; Abdul Rahman and Bukair, 2013). Gray (1988) and Salter and Niswander (1995) showed that measures of national culture can help explain cross-country differences in accounting practices particularly with regard to disclosure level. The analysis shows that culture based on UA has a negative association with disclosure level (Sharia and aggregate). This result is supported by Hope (2003) who showed that cultural values are a determinant of differences between disclosure levels. Consequently, the purpose to achieve international convergence for IFIs, a main goal of 
AAOIFI, should be expanded from merely adopting a single set of high-quality accounting standards to considering the cultural values of Islamic countries as well other countries that have Islamic banks or even Islamic windows around the world.

\section{Conclusion}

We measured to what extent IBs that adopt AAOIFI standards are consistent with AAOIFI requirements. We also associated variations in SSBR, CSRR and financial statements disclosure levels with variations in both firm characteristics and corporate governance mechanisms related to BOD and SSB. The findings of this study illustrate a relatively low average level of compliance with AAOIFI disclosures related to social requirements (27\%). It also indicates a relatively high average level of compliance with AAOIFI disclosures related to Sharia and financial requirements. This approximates to $68 \%$ for SSBR and $73 \%$ for financial disclosure level. We find that the corporate governance mechanisms related to SSB have significantly high explanatory power over Sharia disclosure variations compared with corporate governance mechanisms related to BOD. This can be explained based on the fact that AAOIFI standards for our selected banks are mandatory, and BOD does not have a direct role in ensuring compliance with standards, whereas SSB has a significant role in preparing reports about the compliance level with Sharia. We find also that firm characteristics (age, size and SAD) have a significant impact on disclosure variations.

These results have theoretical and practical implications. They suggest that more attention should be paid to variables that may explain the variations in Sharia, social and financial disclosure particularly those concerned with SSB. Our suggestion is consistent with a recent trend in the accounting literature (e.g., Farook et al., 2011; Abdul Rahman and Bukair, 2013) for research to look more deeply at the SSB characteristics of corporate governance. The practical implication of our results lies in our empirical evidence relevant to the importance and benefits of compliance with AAOIFI standards which has a significant impact on the image of IBs as well as approving Sharia compliance and serving society, which represent the main competitive advantages for these banks. Our results suggest that more attention should be paid to adoption of AAOIFI particularly for IBs who are members without adopting. Looking more closely at the variations in compliance with AAOIFI and the disclosure levels between the IBs in each country is useful for clearly identifying the extent to which the regulatory approach relies on either regulations or mandatory and voluntary disclosure. Furthermore, AAOIFI should take measures to make their standards mandatory for all their members as a first step to making it compulsory for all IFIs. When we measured the disclosure levels for each country, we found that Bahrain is located in the fourth place after Jordan, Syria and Palestine. Consequently, we recommend that the Central Bank of Bahrain further investigate this issue and explore the reasons and the scope for enhancing compliance with AAOIFI.

Our results related to compliance levels of banks with AAOIFI adds significantly to Islamic accounting literature by emphasising the importance of widening this research scope to pay more attention to variations above the mandated requirements (AAOIFI adoption), which provide a minimum amount of information to all stakeholders. The results indicate that organising reporting by IBs that formally implement an accounting standard (AAOIFI) significantly improves the disclosure level for Sharia compliance by encouraging them to care about their SSB report. The results support the current trend in the regulations in Bahrain, Sudan and Jordan, which encourage the mandatory adoption of AAOIFI by IBs. The un-weighted disclosure index is adapted to 
measure the compliance level with AAOIFI. However, this kind of disclosure index has an important limitation as the number of disclosure items required by different standards varies considerably. As in our research, some standards require a large number of items (104 items) to be disclosed (Accounting Standard No.1) whereas others require only a few items (15 items) to be disclosed (Governance Standard No.1). This may become a significant problem when studies examine compliance with AAOIFI disclosures. An alternative method recommended for future research to avoid this problem is the "partial compliance un-weighted approach" which was employed by Street and Gray (2001)). Furthermore, our paper only focused on 3 AAOIFI standards and further research may examine other standards.

Further research could consider other variables that might affect compliance levels such as GDP, corruption index, and audit committee, leverage, ownership structure and other culture dimensions. In this study, the sample is restricted to Islamic banks in 8 countries that adopted AAOIFI standards during 2013. Further studies could extend the sample to other countries that have IBs and extend the covered period. Future research could also investigate the level and determinants pf compliance levels with AAOIFI standards for other financial institutions. Finally, additional research could be undertaken to examine the economic consequences of the compliance with AAOIFI standards.

\section{References}

AAOIFI, (2010), corporate social responsibility conduct and disclosure for Islamic financial institutions (Governance standard No.7), Accounting and Auditing Organization for Islamic Financial Institutions (AAOIFI), Bahrain

AAOIFI, (2010), General Presentation and Disclosure in the Financial Statements of Islamic Banks and Financial Institutions (No.1), AAOIFI, Bahrain. 
AAOIFI, (2010), Sharia Supervisory Board: Appointment, Compositions and Report (Financial standard No.1), AAOIFI, Bahrain.

AAOIFI, (2010), Sharia Review (Governance standard No.2), AAOIFI, Bahrain.

AAOIFI, (2010), Independence of Sharia Supervisory Board (Governance standard No.5), AAOIFI, Bahrain

Abdul Rahman, A. \& Bukair, A. (2013). “The Influence of the Sharia Supervision Board on Corporate Social Responsibility Disclosure by Islamic Banks of Gulf Co-Operation Council Countries". Asian Journal of Business and Accounting, 6(2): 65-104.

Aggarwal, R. \& Yousef, T. (2000). "Islamic banks and investment financing". Journal of Money, Credit and Banking, 32 (1), 93-120

Ahmed, K. \& Nicholls, D. (1994). "The impact of non-financial company characteristics on mandatory disclosure compliance in developing countries: The case of Bangladesh". The International Journal of Accounting, 29, 62-77

Ahmed, K. \& Courtis, J. (1999). “Associations between corporate characteristics and disclosure levels in annual reports: a meta- analysis”. British Accounting Review, 31 (1), 35-61

Ahmed, N. \& Khatun, M. (2013). "The compliance with Sharia governance system of AAOIFI: A study on Islamic banks Bangladesh". Journal of Islamic Economics, Banking and Finance, 9 (3), 178-191

Alsaeed, K. (2005). "The association between firm-specific characteristics and disclosure: The Case of Saudi Arabia". Journal of American Academy of Business, Cambridge, 7/1, 310-321

Aras, G. Aybars, A. \& Kutlu, O. (2010). "Managing corporate performance: Investigating the Relationship between corporate social responsibility and financial performance in emerging markets". International Journal of Productivity and Performance Management, 59 (3), 229-254

Archambeault, D. DeZoort, T. \& Holt, T. (2008). “The need for an internal auditor report to External Stakeholders to improve governance transparency”. Accounting Horizons, 22 (4), 375-388

Arcay, R. \& Vazquez, F. (2005). "Corporate characteristics, governance rules and the extent of voluntary disclosure in Spain”. Advances in Accounting, 21, 299-331

Aribi, Z. \& Gao, S. (2012). “Corporate social responsibility disclosure: A comparison between Islamic and conventional financial institutions". Journal of Financial Reporting and Accounting, 8 (2), 72-91

Bailey, A. Gramling, A. \& Ramamoorti, S. (2003). Research Opportunities in Internal Auditing, Altamonte Springs, FL: The IIA Research Foundation.

Barako, G. Hancock, P. \& Izan, H. (2006). "Factors influencing voluntary corporate disclosure by Kenyan Companies". Corporate Governance: An International Review, 14 (2), 107-125

Belal, A. Abdelsalam, O. \& Nizamee, S. (2014). "Ethical reporting in Islamic bank Bangladesh Limited (1983-

2010)". Journal of Business Ethics, 129, 4, 769-784.

Birnbaum, P. (1984). "The choice of strategic alternatives under increasing regulation in high technology Industries". Academy of Management Journal, 27(3), 489-510

Carcello, J. Hermanson, D. \& Raghunandan, K. (2005). "Changes in internal auditing during the time of the major U.S. accounting scandals". International Journal of Auditing, 9 (2), 117-27

Chalmers, K. \& Godfrey, J. (2004). "Reputation costs: the impetus for voluntary derivative financial instrument Reporting”. Accounting, Organizations and Society, 29 (2), 95-125

Chau, G. \& Leung, P. (2006). "The impact of board composition and family ownership on Audit Committee formation: Evidence from Hong Kong”. Journal of International Accounting, Auditing \& Taxation, 15 (1), 1-15

Cheng, C. \& Courtenay, M. (2006). "Board composition, regulatory regime and voluntary disclosure". The International Journal of Accounting, 41, 262-289

Chen, C. \& Jaggi, B. (2000). "Association between independent non-executive directors, Family Control and financial disclosures in Hong Kong". Journal of Accounting and Public Policy, 19, 285-310

Cooke, E. (1998). "Regression analysis in accounting disclosure studies". Accounting and Business Research, 28(3), 209-224

Cooke, E. (1989). "Voluntary corporate disclosure by Swedish companies". Journal of International Financial Management and Accounting, 1 (2), 171-195

Cormier, D. Magnan, M. \& Van Velthoven, B. (2005). "Environmental disclosure quality in large German economic incentives". European Accounting Review, 14, 1, 3-39.

Dahya, J. Lonie, A. \& Power, M. (1996). "The case for separating the roles of chairman and CEO: An analysis of stock market and accounting data”. Corporate Governance: An International Review, 4 (2), 52-68

Datar, S. Feltham, G. \& Hughes, J. (1991). "The role of auditor and auditor quality in valuing new issues". Journal of Accounting and Economics, 14, 3-49

Doupnik, T. \& Tsakumis, G. (2004). “A critical review of tests of Gray’s theory of cultural relevance and 
suggestions for future research". Journal of Accounting Literature, 23, 1-48

Elshandidy, T. Fraser, I. \& Hussainey, K. (2013). “Aggregated, voluntary, and mandatory risk disclosure incentives: Evidence from UK FTSE All-share companies. International Review of Financial Analysis, 30, 320333

Eng, L. \& Mak, T. (2003). "Corporate governance and voluntary disclosure”. Journal of Accounting and Public Policy, 22, 325-345

Fama, E. \& Jensen, M. (1983). "Separation of ownership and control”. Journal of Law and Economics, 26 (2), 301325

Fama, F. (1980). "Agency problems and the theory of the firm”. Journal of Political Economy, 88, 88-307

Farook, S. Hassan, K. Lanis, R. (2011). "Determinants of corporate social responsibility: the case of Islamic Banks". Journal of Islamic Accounting and Business Research 2 (2), 114-141

Fekete, S. Matis, D. \& Lukács, J. (2008). "Factors influencing the extent of corporate compliance with IFRS - the case of Hungarian listed companies", Available at SSRN http:// ssrn.com/abstract $=1295722$

Glaum, M. \& Street, D. (2003). "Compliance with the disclosure requirements of Germany's new market: IAS versus US GAAP”. Journal of international financial management and accounting, 14(1), 64-100

Gordon, L. \& Smith, K. (1992). "Post auditing capital expenditures and firm performance". Accounting, Organizations and Society, 17 (8), 741-57

Grais, W. \& Pellegrini, M. (2006). "Corporate governance and Sharia compliance in institutions offering Islamic financial services”, Working Paper, World Bank Policy Research

Gramling, A. Marletta, M. \& Church, B. (2004). «The role of the internal audit functions in corporate governance: A synthesis of the extant internal audit literature and directions for future research". Journal of Accounting Literature, 23, 194-244

Gray, R. Javad, M. Power, M. \& Sinclair, C. (2001). "Social and environmental disclosure and corporate characteristics: a research note and extension”. Journal of Business Finance and Accounting, 28 (3\&4), 327-356

Gray J. (1988). "Towards a theory of cultural influence on the development of accounting systems Internationally". Abacus, 24 (2), 1-15

Gul, F. \& Leung, S. (2004). "Board leadership, outside directors' expertise and voluntary corporate disclosure". Journal of Accounting and Public Policy, 23 (5), 351-379

Haat, M. Abdul Rahman, R. \& Mahenthiran, S. (2008). "Corporate governance, transparency and performance of Malaysian companies”. Managerial Auditing Journal, 33 (8), 744-778

Hafij, U. (2013). "Compliance of AAOIFI guidelines in general presentation and disclosure in the financial statements of Islamic banks in Bangladesh". International Journal of Social Science Research, 1 (2), 111-123

Haniffa, R. \& Hudaib, M. (2007). "Exploring the ethical identity of Islamic banks via communication in annual reports”. Journal of Business Ethics, 76, 97-116

Haniffa, M. \& Cooke, E. (2002). "Culture, corporate governance and disclosure in Malaysian corporations". Abacus, 38, 317-349

Haniffa, R. (2002) "Social responsibility disclosure: An Islamic perspective”. Indonesian Management and Accounting Journal, 1 (2), 128-146

Hassan, A. Harahap, S. (2010). "Exploring corporate social responsibility disclosure: the case of Islamic banks". International Journal of Islamic and Middle Eastern Finance and Management, 3 (3), 203- 227

Hassan,O. Giorgioni, G. \& Romilly, P. (2006). "The extent of financial disclosure and its determinants in an emerging capital market: The case of Egypt". International Journal of Accounting, Auditing and Performance Evaluation, 3 (1), 41-67

Healy, P. \& Palepu, K. (2001). "Information asymmetry, corporate disclosure, and the capital markets: A review of the empirical disclosure literature”. Journal of Accounting and Economics, 31 (2001) 405-440

Ho, S. \& Wong, R. (2001). "A study of the relationship between corporate governance structures and the extent of voluntary disclosure”. Journal of International Accounting, Auditing and Taxation, 10, 139-156

Hodgdon, C. Tondkar, R. Adhikari, A. \& Harless, D. (2009). "Compliance with International Financial Reporting Standards and auditor choice: New evidence on the importance of the statutory audit". The International Journal of Accounting, 44 (1), 33-55

Hofstede, G. (2001). Culture's consequences: Comparing Values, Behaviours, Institutions and Organizations across Nations ( $2^{\text {nd }}$ ed), London: Sage Publications

Hope, O. (2003). "Disclosure practices, enforcement of accounting standards, and analysts' forecast accuracy: An international study". Journal of Accounting Research, 41 (2), 235-272

Hossain, M. \& Hammami, H. (2009). "Voluntary disclosure in the annual reports of an emerging country: The 
case of Qatar". Advances in Accounting; Incorporating International Advances in Accounting, 25, 255-265

Hossain, M. Perera, M. H. B. \& Rahman, A. R. (1995). "Voluntary disclosure in the annual reports of New Zealand companies". Journal of International Financial Management and Accounting, 6 (1), 69-85

Hossain, M. Tan, L. M. \& Adams, M. (1994). "Voluntary disclosure in an emerging capital market: Some empirical evidence from companies listed on the Kuala Lumpur stock exchange". International Journal of Accounting, 29 (4), 334-351

Hussain, S. \& Mallin, C. (2003). "The dynamics of corporate governance in Bahrain: structure, responsibilities and operation of corporate boards". Corporate Governance: An International Review, 11 (3), 249-262

Inchausti, G. (1997). "The influence of company characteristics and accounting regulation on information disclosed by Spanish firms". The European Accounting Review, 6, 45-68

Jaggi, B. \& Low, P. (2000). "Impact of culture, market forces, and legal system on financial disclosures". International Journal of Accounting, 35 (4), 495-519

Khlif, H. \& Hussainey, K. (2014). "The association between risk disclosure and firm characteristics: a metaAnalysis". Journal of Risk Research, forthcoming, DOI:10.1080/13669877.2014.961514

Kuran, T. (2003). Islamic redistribution through Zakat: historical record and modern realities, in Bonner, M., Ener, M. and Singer, A. (Eds), Poverty and Charity in Middle Eastern Contexts, State University of New York Press, Albany, NY, 275-294

Laksmana, I. (2008). "Corporate board governance and voluntary disclosure of executive Compensation Practices". Contemporary Accounting Research, 25 (4), 47-82

La Porta, R. Lopez-de-Silanes, F. Shleifer, A. \& Vishny, R. (2002). "Investor protection and corporate valuation". Journal of Finance, 57, 1147-1170

Lewis, M. \& Algaoud, L. (2001). Islamic Banking, Edward Elgar Publishing Ltd, USA.

Lorsch, J. \& MacIver, E. (1989). Pawns or Potentates: The Reality of America’s Corporate Boards. Harvard Business School, Press

Maali, B. Casson, P. \& Napier, C. (2006). "Social reporting by Islamic banks", Abacus, 42(2), 266-290

Mangena, M. \& Tauringana, V. (2007). "Corporate compliance with non-mandatory statements of best practice: The case of the ASB Statement on interim reports". The European Accounting Review, 16(2), 399-427

Mangena, M. \& Pike, R. (2005). "The effect of audit committee shareholding, financial expertise and size on interim financial disclosures". Accounting and Business Research, 35 (4), 327-349

Marston, C. \& Polei, A. (2004). “Corporate reporting on the internet by German companies”. International Journal of Accounting Information Systems, 5, 285-311

Mercer, M. (2004). "How do investors assess the credibility of management disclosures". Accounting Horizons, 18 (3), 185-196

Owusu-Ansah, S. (1998). "The impact of corporate attributes on the extent of mandatory disclosure and reporting by listed companies in Zimbabwe". The International Journal of Accounting, 33, 605-631

Peasnell, K. Pope, P. \& Young, S. (2005). "Board monitoring and earnings management: Do outside directors influence abnormal accruals". Journal of Business Finance and Accounting, 32 (7\&8), 1311-1346

Pincus, K. Rusbarsky, M. \& Wong, J. (1989). "Voluntary formation of corporate audit committees among NASDAQ firms". Journal of accounting and public policy, 8 (4), 239-323

Rahman, A. Perera, H. \& Ganesh, S. (2002). "Accounting practices harmony". Accounting regulation and firm Characteristics. Abacus, 38, 46-77

Rajab, B. \& Handley-Schachler, M. (2009). "Corporate risk disclosure by UK firms: trends and determinants". World Review of Entrepreneurship. Management and Sustainable Development, 5 (3), 224-43

Salter, S. \& Niswander, F. (1995). "Cultural influences on the development of accounting Systems Internationally: a test of Gray (1988) theory". Journal of International Business Studies, 26 (2), 379-397

Samaha, K. \& Dahawy, K. (2011). "An empirical analysis of corporate governance structures and voluntary corporate disclosure in volatile capital markets: The Egyptian experience". International Journal of Accounting, Auditing and Performance Evaluation, 7, 61-93

Sarea, A. \& Hanefah, M. (2013). "The need of accounting standards for Islamic financial institutions: evidence from AAOIFI". Journal of Islamic Accounting and Business Research, 4 (1), 64- 76

Schadewitz, H. \& Blevins, D. (1998). "Major determinants of interim disclosures in an emerging market". American Business Review, 16 (1), 41-55

Schneider, A. \& Wilner, N. (1990). "A test of audit deterrent to financial reporting Irregularities using the randomized response technique". The Accounting Review, 65 (3), 668-681

Singh, M. Mathur, I. \& Gleason, K. (2004). "Governance and performance implications of diversification strategies: evidence from large US firms”. Financial Review, 39, 489-526

Soderstrom, N. \& Sun, K. (2007). "IFRS adoption and accounting quality: A review". The European Accounting 
Review, 16(4), 675-702

Street, D. \& Gray. S. (2001). Observance of International Accounting Standards: Factors Explaining Non-

Compliance by Companies Referring to the Use of IAS. Research monograph, London, U.K.: Association of Chartered Certified Accountants

Ullah, M. (2013). Accounting and Reporting Practices of Islamic Banks in Bangladesh. PhD. University of Chittagong, Bangladesh

Vinnicombe, T. (2010). “AAOIFI reporting standards: measuring compliance”. Advances in Accounting. Incorporating Advances in International Accounting, 26(1), 55-65

Wilson, T. \& Walsh, C. (1996). Information Behaviour: An Interdisciplinary Perspective. Wetherby, West Yorkshire, UK: The British Library Board

Xiao, Z. Yang, H. \& Chow, C. (2004). "Patterns and determinants of internet-based corporate disclosure in China". Journal of Accounting and Public Policy, 23 (3), 191-225

Table (1): Ensuring validity of research instrument

\begin{tabular}{|c|c|c|c|c|c|}
\hline Standards & $\begin{array}{l}\text { Items } \\
\text { suggested by } \\
\text { the author }\end{array}$ & $\begin{array}{l}\text { Items suggested } \\
\text { by independent } \\
\text { researcher }\end{array}$ & $\begin{array}{l}\text { Items suggested by } \\
\text { second independent } \\
\text { researcher }\end{array}$ & $\begin{array}{l}\text { Final index (after } 4^{\text {th }} \\
\text { person's advice) }\end{array}$ & Weight \\
\hline FSIFI.1 & 110 & 105 & 100 & 104 & $49 \%$ \\
\hline GSIFI.1 & 18 & 20 & 15 & 15 & $7 \%$ \\
\hline GSIFI.7 & 90 & 100 & 94 & 95 & $44 \%$ \\
\hline Total & 218 & 225 & 209 & 214 & $100 \%$ \\
\hline
\end{tabular}

The weight is calculated based on final items for each standard dividend into total items (214). For example: weight of FSIFI. $1=104 / 214 * 100=49 \%$

Table (2): Summary of variable names, description and sources

\begin{tabular}{|c|c|c|c|c|c|}
\hline $\begin{array}{l}\text { Abbreviated } \\
\text { name }\end{array}$ & Full name & Variable description & $\begin{array}{c}\text { Predicted } \\
\text { sign }\end{array}$ & Data source & Supporting from literature \\
\hline \multicolumn{6}{|c|}{ Dependent variables } \\
\hline SSB Disc & $\begin{array}{l}\text { Sharia Supervisory } \\
\text { Board disclosure }\end{array}$ & $\begin{array}{l}\text { Sharia disclosure accountability } \\
\text { level based on SSB report }\end{array}$ & & $\begin{array}{l}\text { Annual } \\
\text { reports }\end{array}$ & \\
\hline CSR Disc & $\begin{array}{l}\text { Corporate Social } \\
\text { Responsibility } \\
\text { disclosure }\end{array}$ & $\begin{array}{l}\text { Social disclosure accountability } \\
\text { level based on CSR report }\end{array}$ & & $\begin{array}{l}\text { Annual } \\
\text { reports }\end{array}$ & \\
\hline FIN Disic & Financial disclosure & $\begin{array}{l}\text { Financial disclosure accountability } \\
\text { level based on FS and footnotes }\end{array}$ & & $\begin{array}{l}\text { Annual } \\
\text { reports }\end{array}$ & \\
\hline OVER Disc & Overall disclosure & $\begin{array}{l}\text { SSBR Disclosure+ CSRR } \\
\text { Disclosure+ FIN Disclosure }\end{array}$ & & $\begin{array}{l}\text { Annual } \\
\text { reports }\end{array}$ & \\
\hline \multicolumn{6}{|c|}{$\begin{array}{l}\text { Independent variables } \\
\text { 1. Firm-specific characteristics }\end{array}$} \\
\hline Auditor & Auditor & $\begin{array}{l}\text { Dichotomous; } 1=\text { Bank's financial } \\
\text { statements were audited by Big } 4 \\
\text { auditor; otherwise: } 0\end{array}$ & + & Annual report & Datar et al., 1991, xiao et al., 2004 \\
\hline AGE & Age of bank & $\begin{array}{l}\text { Age of Islamic bank based on } \\
\text { establish date }\end{array}$ & + & Annual report & $\begin{array}{l}\text { Cormier et al., 2005; Hossain and } \\
\text { Hammami, } 2009\end{array}$ \\
\hline SIZE & Size of the bank & Log for total assets & + & $\begin{array}{l}\text { Banker } \\
\text { database }\end{array}$ & $\begin{array}{l}\text { Beretta and Bozzolan, } 2004 \text {, Elshandidy } \\
\text { et al. } 2011 \text {, Vandemele et al. } 2009\end{array}$ \\
\hline PROF & $\begin{array}{l}\text { Profitability of the } \\
\text { bank }\end{array}$ & ROA (Return On Assets) & + & $\begin{array}{l}\text { Banker } \\
\text { database }\end{array}$ & $\begin{array}{l}\text { Wallace et al. 1994, Hussainey and Al- } \\
\text { Najjar, } 2011\end{array}$ \\
\hline SAD & $\begin{array}{l}\text { Sharia Auditing } \\
\text { department }\end{array}$ & $\begin{array}{l}\text { Dichotomous; } 1=\text { Bank that has } \\
\text { Sharia auditing department; } \\
\text { otherwise: o }\end{array}$ & + & Annual report & $\begin{array}{l}\text { Besar et al., 2009; Gramling et al., 2004; } \\
\text { Carcello et al., 2005; Gadziala, 2005; } \\
\text { Archambeault et al. } 2008\end{array}$ \\
\hline \multicolumn{6}{|c|}{ 2. Corporate Governance characteristics for BOD } \\
\hline BLOCK & $\begin{array}{l}\text { Number of Block } \\
\text { holders }\end{array}$ & $\begin{array}{l}\text { Number of block holders- } \\
\text { shareholders whose ownership } \\
\geq 5 \% \text { of total number of shares } \\
\text { issued. }\end{array}$ & - & $\begin{array}{l}\text { Banker and } \\
\text { Zawya } \\
\text { database }\end{array}$ & $\begin{array}{l}\text { Mitchell, Chia, \& Loh, 1995; Schadewitz } \\
\text { \& Blevins, 1998; Hossain et al., } 1994\end{array}$ \\
\hline INST & $\begin{array}{l}\text { Institutional } \\
\text { ownership }\end{array}$ & $\begin{array}{l}\text { Percent of shares owned by } \\
\text { Institutional shareholders }\end{array}$ & + & $\begin{array}{l}\text { Banker and } \\
\text { Zawya } \\
\text { database }\end{array}$ & $\begin{array}{l}\text { Eng and Mak, 2003; Mangena and Pike, } \\
2005\end{array}$ \\
\hline FORGN & Foreign Ownership & $\begin{array}{l}\text { Percent of shares owned by } \\
\text { Foreign shareholders }\end{array}$ & + & $\begin{array}{l}\text { Banker and } \\
\text { Zawya } \\
\text { database }\end{array}$ & Hossain et al., 1994; Xiao et al. 2004 \\
\hline DUAL & Duality in position & $\begin{array}{l}\text { Dummy variable; } 1 \text { if company's } \\
\text { CEO serves as a board chairman, } \\
\text { otherwise: } 0\end{array}$ & - & $\begin{array}{l}\text { Banker and } \\
\text { Zawya } \\
\text { database }\end{array}$ & $\begin{array}{l}\text { Haniffa and Cooke, 2002; Lakhal, 2005; } \\
\text { Laksmana, 2008; Eng and Mak, 2003; } \\
\text { Gul and Leung, } 2004\end{array}$ \\
\hline BINDEP & Board independence & $\begin{array}{l}\text { Ratio of the number of non- } \\
\text { executive directors to the total } \\
\text { number of the directors }\end{array}$ & + & $\begin{array}{l}\text { Banker and } \\
\text { Zawya } \\
\text { database }\end{array}$ & $\begin{array}{l}\text { Haniffa and Cooke, 2002, Hussainey and } \\
\text { Al-Najjar, 2011; Abdelsalam \& Street, } \\
\text { 2007; Chen and Jaggi, } 2000\end{array}$ \\
\hline
\end{tabular}




\begin{tabular}{|c|c|c|c|c|c|}
\hline \multicolumn{6}{|c|}{ 3. Corporate Governance characteristics for SSB } \\
\hline SSBSIZE & $\begin{array}{l}\text { The number of the } \\
\text { SSB }\end{array}$ & $\begin{array}{l}\text { Dichotomous } 1 \text { for banks with } 5 \\
\text { or more members and } 0 \text { less than } \\
5\end{array}$ & + & $\begin{array}{l}\text { Annual } \\
\text { reports and } \\
\text { Website }\end{array}$ & $\begin{array}{l}\text { Singh et al. 2004, Lakhal, 2005, Abdel- } \\
\text { Fattah et al. 2008, Akhatruddin et al., } \\
\text { 2009; Rahman and Bukair, } 2013\end{array}$ \\
\hline SSBREPU & $\begin{array}{l}\text { The SSB having at } \\
\text { least one of them sit } \\
\text { on the board of } \\
\text { AAOIFI }\end{array}$ & $\begin{array}{l}\text { Dichotomous: reputable SSB } \\
\text { member: } 1 \text {, otherwise: } 0 \\
\text { (Reputable scholar is one that has } \\
\text { a position in SSB of AAOIFI and at } \\
\text { least one SSB memberships) }\end{array}$ & + & $\begin{array}{l}\text { Annual } \\
\text { reports and } \\
\text { Website }\end{array}$ & $\begin{array}{l}\text { Hussain and Mallin, 2003, Farook et al., } \\
\text { 2011; Rahman and Bukair, } 2013\end{array}$ \\
\hline SSBCROSS & $\begin{array}{l}\text { Cross membership of } \\
\text { SSB }\end{array}$ & $\begin{array}{l}\text { Dichotomous: SSB member with a } \\
\text { cross membership in more than } \\
\text { one Islamic bank: } 1 \text {, otherwise: } 0\end{array}$ & + & $\begin{array}{l}\text { Annual } \\
\text { reports and } \\
\text { website }\end{array}$ & $\begin{array}{l}\text { Farook et al., 2011, Haat et al., 2008; } \\
\text { Haniffa and Cooke, 2002; Rahman and } \\
\text { Bukair, } 2013\end{array}$ \\
\hline \multicolumn{6}{|l|}{ 4. Culture } \\
\hline UNCER & $\begin{array}{l}\text { Uncertainty } \\
\text { avoidance }\end{array}$ & $\begin{array}{l}\text { Score for each country based on } \\
\text { data of Green Hofstede center }\end{array}$ & - & $\begin{array}{l}\text { Green } \\
\text { Hofstede } \\
\text { center }\end{array}$ & Khlif and hussainey, 2014; Wong, 2012 \\
\hline
\end{tabular}

Following the collapse of Arthur Andersen in 2002, the Big 5 became Big 4, namely: PricewaterhouseCoopers, Deloitte Touche Tohmatsu, Ernst and Young and KPMG (Bokpin, 2013)

Firm profitability (PRF) is measured by return on assets which is a more powerful measure of performance as compared to return on equity. Return on assets is used here as a measure of overall earnings power of the company (Bokpin, 2013)

Dichotomous is a concept used to describe a variable that consists of only two categories (0 \&1) (Field, 2006)

Uncertainty avoidance, which is the degree to which individuals in a country prefer structured over unstructured situations, from relatively

flexible to extremely rigid, to cope with risk and innovation; a low uncertainty culture emphasises a higher level of standardisation (Hofstede, 1991, 2001)

Table (3): Disclosure and compliance level by bank

\begin{tabular}{|c|c|c|c|c|c|c|c|c|c|}
\hline \multirow[t]{2}{*}{ Bank } & \multicolumn{3}{|c|}{ Average Compliance $\%$} & \multirow{2}{*}{$\begin{array}{c}\text { Total } \\
\text { disclosure } \%\end{array}$} & \multirow[t]{2}{*}{ Bank } & \multicolumn{3}{|c|}{ Average Compliance \% } & \multirow{2}{*}{$\begin{array}{c}\text { Total } \\
\text { disclosure } \%\end{array}$} \\
\hline & Sharia & Social & Financial & & & Sharia & Social & Financial & \\
\hline Tadhamon International Islamic Bank & $40 \%$ & $13 \%$ & $85 \%$ & $46 \%$ & Qatar Islamic Bank & $60 \%$ & $36 \%$ & $88 \% * * *$ & $61 \%$ \\
\hline Saba Islamic Bank, Sana & $86 \%$ & $16 \%$ & $87 \%$ & $63 \%$ & Q invest bank & $46 \%$ & $17 \%$ & $80 \%$ & $48 \%$ \\
\hline Shamil Bank of Yemen \& Bahrain & $60 \%$ & $21 \%$ & $72 \%$ & $51 \%$ & Faisal Islamic Bank Sudan & $73 \%$ & $20 \%$ & $67 \%$ & $53 \%$ \\
\hline Al Baraka Islamic Bank & $86 \%$ & $49 \%$ & $73 \%$ & $69 \%$ & Al Shamal Islamic Bank & $60 \%$ & $18 \%$ & $63 \%$ & $47 \%$ \\
\hline Khaleeji Commercial Bank & $27 \%$ & $24 \%$ & $87 \%$ & $46 \%$ & Animal Resources Bank & $6 \%$ & $16 \%$ & $75 \%$ & $32 \%$ \\
\hline First Energy Bank & $80 \%$ & $25 \%$ & $74 \%$ & $60 \%$ & Saving \& Social Development Bank & $53 \%$ & $47 \%$ & $68 \%$ & $56 \%$ \\
\hline Arab Banking Corporation & $73 \%$ & $25 \%$ & $77 \%$ & $58 \%$ & Farmer's Commercial Bank & $66 \%$ & $20 \%$ & $61 \%$ & $49 \%$ \\
\hline Bahrain Islamic Bank & $93 \% *$ & $46 \%$ & $77 \%$ & $72 \%$ & Al Salam Bank & $53 \%$ & $18 \%$ & $65 \%$ & $45 \%$ \\
\hline Venture CapitalBank & $73 \%$ & $21 \%$ & $62 \%$ & $52 \%$ & Blue Nile Mahsreg Bank & $6 \%$ & $17 \%$ & $61 \%$ & $28 \%$ \\
\hline Ithmaar Bank & $73 \%$ & $12 \%$ & $83 \%$ & $56 \%$ & Al Jazeera Sudanese Jordanian Bank & $66 \%$ & $19 \%$ & $57 \%$ & $47 \%$ \\
\hline Gulf Finance House & $80 \%$ & $21 \%$ & $86 \%$ & $62 \%$ & Al-Nile bank & $73 \%$ & $18 \%$ & $72 \%$ & $54 \%$ \\
\hline Al Salam Bank of Bahrain & $80 \%$ & $18 \%$ & $72 \%$ & $57 \%$ & Tadamon Islamic Bank & $53 \%$ & $16 \%$ & $61 \%$ & $43 \%$ \\
\hline Bank Al-khair & $80 \%$ & $19 \%$ & $77 \%$ & $59 \%$ & United Capital Bank & $73 \%$ & $17 \%$ & $64 \%$ & $51 \%$ \\
\hline Global Banking Corporation & $73 \%$ & $22 \%$ & $78 \%$ & $58 \%$ & Jordan Islamic Bank & $80 \%$ & $60 \%$ *** & $72 \%$ & $71 \%$ \\
\hline Seera Investment Bank BSC & $60 \%$ & $12 \%$ & $63 \%$ & $45 \%$ & Islamic Intemational Arab Bank & $60 \%$ & $46 \%$ & $83 \%$ & $63 \%$ \\
\hline International Investment Bank & $80 \%$ & $13 \%$ & $62 \%$ & $52 \%$ & Jordan Dubai Islamic bank & $80 \%$ & $39 \%$ & $67 \%$ & $62 \%$ \\
\hline Citi Islamic Investment Bank & $60 \%$ & $9 \%$ & $74 \%$ & $48 \%$ & Syria Intemational Islamic Bank & $80 \%$ & $21 \%$ & $63 \%$ & $55 \%$ \\
\hline Investors Bank & $60 \%$ & $7 \%$ & $62 \%$ & $43 \%$ & Cham Bank & $93 \% *$ & $23 \%$ & $81 \%$ & $66 \%$ \\
\hline Qatar International Islamic Bank & $46 \%$ & $17 \%$ & $66 \%$ & $43 \%$ & Arab Islamic Bank & $60 \%$ & $41 \%$ & $84 \%$ & $62 \%$ \\
\hline Qatar First Investment Bank & $93 \% *$ & $19 \%$ & $63 \%$ & $58 \%$ & The Palestine Islamic Bank & $80 \%$ & $42 \%$ & $79 \%$ & $67 \%$ \\
\hline Barwa Bank & $66 \%$ & $15 \%$ & $66 \%$ & $49 \%$ & Bank Nizwa & $66 \%$ & $21 \%$ & $66 \%$ & $51 \%$ \\
\hline Masraf Al Rayan & $60 \%$ & $16 \%$ & $66 \%$ & $47 \%$ & & & & & \\
\hline
\end{tabular}

* The highest banks score for sharia disclosure; ** the highest bank score for social and *** the highest bank score for financial disclosure level

Table (4): Level of compliance by country 


\begin{tabular}{|c|c|c|c|c|c|c|c|}
\hline \multirow[t]{2}{*}{ Country } & \multirow{2}{*}{$\begin{array}{l}\text { No. of } \\
\text { banks }\end{array}$} & \multirow{2}{*}{$\begin{array}{c}\% \text { banks } \\
\text { from sample }\end{array}$} & \multicolumn{3}{|c|}{ Average Compliance \% } & \multirow{2}{*}{$\begin{array}{l}\text { Total Average } \\
\text { Compliance } \%\end{array}$} & \multirow{2}{*}{$\begin{array}{l}\text { Ranking } \\
\text { of country }\end{array}$} \\
\hline & & & sharia & Social & Financial & & \\
\hline Yemen & 3 & $7 \%$ & $62 \%$ & $17 \%$ & $81 \%$ & $53 \%$ & 5 \\
\hline Bahrain & 15 & $35 \%$ & $72 \%$ & $22 \%$ & $74 \%$ & $56 \%$ & 4 \\
\hline Qatar & 6 & $14 \%$ & $62 \%$ & $20 \%$ & $72 \%$ & $\mathbf{5 1} \%$ & 6 \\
\hline Sudan & 11 & $25 \%$ & $53 \%$ & $21 \%$ & $65 \%$ & $46 \%$ & 7 \\
\hline Jordan & 3 & $7 \%$ & $73 \%$ & $48 \% * *$ & $74 \%$ & $65 \%$ & $\mathbf{1}$ \\
\hline Syria & 2 & $5 \%$ & $87 \% *$ & $22 \%$ & $72 \%$ & $60 \%$ & 3 \\
\hline Palestine & 2 & $5 \%$ & $70 \%$ & $42 \%$ & $82 \% * * *$ & $64 \%$ & 2 \\
\hline Oman & 1 & $2 \%$ & $66 \%$ & $21 \%$ & $66 \%$ & $\mathbf{5 1} \%$ & 6 \\
\hline Average & 43 & $100 \%$ & $68 \%$ & $27 \%$ & $73 \%$ & $56 \%$ & \\
\hline
\end{tabular}

the highest country score for financial disclosure level

Table (5): Compliance level with AAOIFI governance standards No.1 \& 5 (SSB)

\begin{tabular}{|c|c|c|c|}
\hline & Items and corresponding AAOIFI standards (Sharia oriented disclosure) & & Disclosure \% \\
\hline \multirow{18}{*}{ 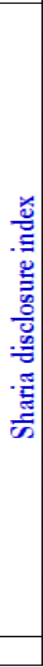 } & Items related to SSB members (SSBM) & \multirow{17}{*}{ 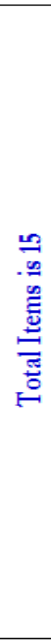 } & $70 \%$ \\
\hline & 1. Names of Sharia board members & & $95 \%$ \\
\hline & $\begin{array}{l}\text { 2. Brief about each members in the Sharia board (Background and } \\
\text { qualifications) }\end{array}$ & & $40 \%$ \\
\hline & 3. The role and responsibilities of the board & & $70 \%$ \\
\hline & 4. The authorities of the board & & $88 \%$ \\
\hline & 5. The Sharia auditing department in the bank & & $65 \%$ \\
\hline & $\begin{array}{l}\text { 6. Is the website or annual report disclose the Fatwa for the SSB related to } \\
\text { Islamic services }\end{array}$ & & $63 \%$ \\
\hline & Items related to SSB report (SSBR) & & $66 \%$ \\
\hline & 7. SSB report assigned from the board members & & $85 \%$ \\
\hline & 8. Information about the bank's responsibilities of Zakat & & $65 \%$ \\
\hline & $\begin{array}{l}\text { 9. Information about the bank's responsibilities of activities not comply with } \\
\text { Sharia and how bank deal with it }\end{array}$ & & $65 \%$ \\
\hline & $\begin{array}{l}\text { 10. Information about how profit distribution process in the bank comply with } \\
\text { Islamic Sharia }\end{array}$ & & $70 \%$ \\
\hline & 11. Information about the independency of the SSB with charter & & $37 \%$ \\
\hline & 12. Information about opinion for the SSB about compliance with Sharia & & $90 \%$ \\
\hline & $\begin{array}{l}\text { 13. The board discloses its opinion after reviewing all documents and all } \\
\text { financial statements for the bank }\end{array}$ & & $74 \%$ \\
\hline & 14. Is the report shows that the bank comply with the AAOIFI's standards & & $22 \%$ \\
\hline & 15. Information about the date of report and name of bank & & $85 \%$ \\
\hline & Average compliance level & 15 & $68 \%$ \\
\hline
\end{tabular}

Table (6): Compliance level with AAOIFI governance standard No.7 (CSR)

\begin{tabular}{|c|c|c|c|}
\hline & Items and corresponding AAOIFI standard & Items & Disclosure \% \\
\hline & A. Univers al oriented CSR disclosure & & $30 \%$ \\
\hline \multirow{14}{*}{ 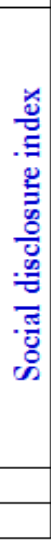 } & 1. Employee welfare & 12 & $30 \%$ \\
\hline & 2. Internal environment preservation policy & 9 & $17 \%$ \\
\hline & 3. Par Excellence customers services & 5 & $35 \%$ \\
\hline & $\begin{array}{l}\text { 4. Micro and small business and social saving and investments } \\
\text { and Development }\end{array}$ & 10 & $33 \%$ \\
\hline & 5. Charitable activates & 6 & $37 \%$ \\
\hline & 6. Social responsibility & 13 & $28 \%$ \\
\hline & B. Sharia oriented CSR disclosure & & $23 \%$ \\
\hline & 7. Late repayments and insolvent clients & 10 & $12 \%$ \\
\hline & 8. Qard Hassan & 10 & $15 \%$ \\
\hline & 9. Zakat & 7 & $35 \%$ \\
\hline & 10. Waqf management & 5 & $2 \%$ \\
\hline & 11. Earning and expenditure prohibited by sharia & 4 & $32 \%$ \\
\hline & 12. Screening and informing clients for compliance with sharia & 4 & $42 \%$ \\
\hline & Average compliance level & 95 & $27 \%$ \\
\hline
\end{tabular}

Table (7): Compliance level with AAOIFI financial standard No.1 (Financial) 


\begin{tabular}{|c|c|c|c|}
\hline & Items and corresponding AAOIFI standard & Total Items & Disclosure \% \\
\hline \multirow{18}{*}{ 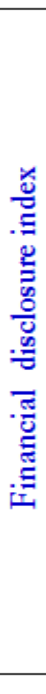 } & \multicolumn{2}{|l|}{ A. Universal oriented financial disclosure } & $86 \%$ \\
\hline & 1. Comparative financial statements & 1 & $100 \%$ \\
\hline & 2. Basic information about the bank & 11 & $83 \%$ \\
\hline & 3. Disclosure of the currency used for accounting measurement & 2 & $88 \%$ \\
\hline & 4. Disclosure of significant accounting policies & 7 & $82 \%$ \\
\hline & 5. Disclosure of contingences & 1 & $83 \%$ \\
\hline & 6. Disclosure of accounting policy changes & 10 & $75 \%$ \\
\hline & 7. Disclosure about assets and liabilities ${ }^{2}$ risk & 3 & $82 \%$ \\
\hline & 8. Presentation and disclosure in the Financial Position & 20 & $88 \%$ \\
\hline & 9. Presentation and disclosure in the Income Statement & 12 & $89 \%$ \\
\hline & 10. Disclosure in the statement of Cash Flows & 6 & $88 \%$ \\
\hline & 11. Statement of Changes in the Owner's Equity & 10 & $85 \%$ \\
\hline & \multicolumn{2}{|l|}{ B. Sharia oriented financial disclosure } & $36 \%$ \\
\hline & 12. Disclosure of earning or expenditure prohibited by sharia & 2 & $45 \%$ \\
\hline & 13. Statement of Changes in Restricted Investments & 12 & $42 \%$ \\
\hline & $\begin{array}{l}\text { 14. Disclosure in the Statement of Sources and Uses of funds } \\
\text { of Zakat and Sadakat }\end{array}$ & 4 & $23 \%$ \\
\hline & $\begin{array}{l}\text { 15. Disclosure in the statement of sources and uses of funds, Loan } \\
\text { Fund (Al Q ard Al Hasan Fund) }\end{array}$ & 3 & $35 \%$ \\
\hline & Average compliance level & 104 & $73 \%$ \\
\hline
\end{tabular}

Table (8): Disclosure about 8 main Islamic services presented

\begin{tabular}{|l|c|c|}
\hline \multicolumn{1}{|c|}{ Main services provided } & No & Disclosure \% \\
\hline Murabaha & 39 & $\mathbf{9 1 \%}$ \\
\hline Mudaraba & 34 & $\mathbf{7 9} \%$ \\
\hline Ijara & 30 & $\mathbf{7 0} \%$ \\
\hline Zakat & 26 & $\mathbf{6 0} \%$ \\
\hline Musharakah & 23 & $\mathbf{5 3} \%$ \\
\hline Sukuk & 21 & $\mathbf{4 9} \%$ \\
\hline Istisna a & 11 & $\mathbf{2 6} \%$ \\
\hline Salam & 5 & $\mathbf{1 2} \%$ \\
\hline
\end{tabular}

Table (9): Overall disclosure levels

\begin{tabular}{|l|c|c|c|c|}
\hline & SSBR & CSR & Financial & Overall \\
\hline Average $\%$ of compliance & $68 \%$ & $27 \%$ & $73 \%$ & $56 \%$ \\
\hline Universal oriented compliance $\%$ & Related to SSBM $70 \%$ & $30 \%$ & $86 \%$ & $58 \%$ \\
\hline Sharia oriented compliance $\%$ & Related to SSBR $66 \%$ & $23 \%$ & $36 \%$ & $42 \%$ \\
\hline
\end{tabular}

\section{SSBM: Sharia Supervisory Board Members}

SSBR: Sharia Supervisory Board Report

Table (10): Descriptive statistics 


\begin{tabular}{|c|c|c|c|c|c|c|}
\hline & Variables & $\mathbf{N}$ & Minimum & Maximum & Mean & Std. Deviation \\
\hline \multirow{4}{*}{ 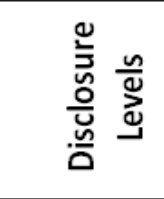 } & SSBR & 43 & 0.06 & 0.93 & 0.678 & 0.19585 \\
\hline & CSRR & 43 & 0.08 & 0.60 & 0.273 & 0.12083 \\
\hline & FIN & 43 & 0.31 & 0.85 & 0.731 & 0.12888 \\
\hline & OVER & 43 & .21 & .74 & 0.560 & .09600 \\
\hline \multirow{5}{*}{ 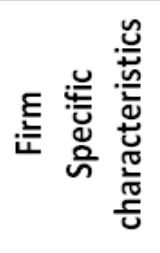 } & AUDIT & 43 & 0.00 & 1.00 & 0.6512 & .48224 \\
\hline & AGE & 43 & 3.00 & 49.00 & 19.255 & 12.16766 \\
\hline & SIZE & 43 & 1.23 & 4.33 & 2.8706 & .67019 \\
\hline & PROFIT & 43 & -13.39 & 21.57 & 1.6814 & 4.66238 \\
\hline & SAD & 43 & 0.00 & 1.00 & .6744 & .47414 \\
\hline \multirow{5}{*}{ 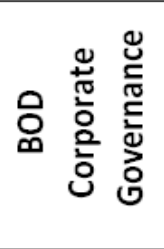 } & BLOOK & 25 & 0.00 & 7.00 & 2.7200 & 1.88237 \\
\hline & FORIGEN & 24 & 0.00 & 1.00 & .6328 & .35791 \\
\hline & INSTITU & 24 & 0.00 & 1.00 & .5750 & .29427 \\
\hline & DUALITY & 30 & 0.00 & 1.00 & .0333 & .18257 \\
\hline & B.INDIP & 24 & 0.00 & 1.00 & .4925 & .31958 \\
\hline \multirow{3}{*}{ 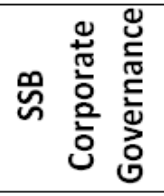 } & SSBSIZE & 43 & 0.00 & 1.00 & .1163 & .32435 \\
\hline & SSBREPU & 42 & 0.00 & 1.00 & .5000 & .50606 \\
\hline & SSBCROSS & 42 & 0.00 & 1.00 & .5714 & .50087 \\
\hline Culture & UNCER & 43 & 60.00 & 80.00 & 71.2558 & 5.61076 \\
\hline \multicolumn{7}{|c|}{$\begin{array}{l}\text { This table provides descriptive statistics for all of the variables defined in Table } 1 \text { which are as follows: } \\
\text { SSBR: Sharia Supervisory Board Report; CSRR: Corporate Social Responsibility Report; FIN: Financial } \\
\text { disclosure that located at financial statements; OVER: Overall disclosure that contain SSBR; CSRR and FIN } \\
\text { AUD: size of Auditor; AGE: Age of bank; SIZE: Size of the bank based on total assets; PROF: Profitability of } \\
\text { the bank based on ROA; SAD: Sharia Auditing department inside the bank; BLOCK: Number of Block } \\
\text { holders; INST: Institutional ownership; FORGN: Foreign Ownership; DUAL: Duality in position; B.INDEP } \\
\text { Board independence; SSBSIZ: The number of Sharia supervisory board members; SSBREPU: The SSB having } \\
\text { at least one of them sit on the board of AAOIFI; SSBCROSS: The SSB having at least one of them sit on the } \\
\text { other Islamic bank' SSB (Cross membership of SSB); UNCER: Uncertainty avoidance }\end{array}$} \\
\hline
\end{tabular}

Table (11): Regression results 


\begin{tabular}{|c|c|c|c|c|c|c|c|c|c|c|c|c|c|c|}
\hline \multirow[t]{3}{*}{ Categories } & \multirow[t]{2}{*}{ Variables } & \multicolumn{3}{|c|}{$\begin{array}{c}\text { Model } 1 \\
\text { Sharia disclosure }\end{array}$} & \multicolumn{3}{|c|}{$\begin{array}{c}\text { Model } 2 \\
\text { Social disclosure }\end{array}$} & \multicolumn{3}{|c|}{$\begin{array}{c}\text { Model } 3 \\
\text { Financial disclosure }\end{array}$} & \multicolumn{3}{|c|}{$\begin{array}{c}\text { Model } 4 \\
\text { Aggregate disclosure }\end{array}$} & \multirow{3}{*}{ VIF } \\
\hline & & Beta & $t$ & Sig & Beta & $t$ & Sig & Beta & $T$ & Sig & Beta & $t$ & Sig & \\
\hline & Constant & & 2.605 & .015 & & 1.140 & .264 & & .993 & .329 & & 3.301 & .003 & \\
\hline \multirow{5}{*}{$\begin{array}{l}\text { Firm-specific } \\
\text { characteristics }\end{array}$} & AUDIT & .156 & .772 & .447 & .252 & 1.437 & .162 & -.054 & -.270 & .789 & .185 & 1.162 & .255 & 2.354 \\
\hline & AGE & .000 & .001 & .999 & .522 & 3.770 & $.001^{* * *}$ & .098 & .619 & .541 & .275 & 2.197 & $.036^{*}$ & 1.466 \\
\hline & SIZE & -.026 & -.152 & .881 & .277 & 1.824 & $.079^{*}$ & .670 & 3.841 & $.001^{* * *}$ & .393 & 2.856 & $.008^{* *}$ & 1.767 \\
\hline & PROFIT & .016 & .105 & .917 & .054 & .399 & .693 & .106 & .679 & .503 & .083 & .677 & .504 & 1.417 \\
\hline & SAD & .443 & 2.757 & $.010^{* * *}$ & .028 & .203 & .841 & .283 & 1.762 & $.089^{*}$ & .187 & 1.472 & .152 & 1.498 \\
\hline Culture & UNCER & -.365 & -1.710 & $.098^{*}$ & -.185 & -.997 & .328 & .004 & .018 & .986 & -.317 & -1.880 & $.071^{*}$ & 2.648 \\
\hline \multirow{5}{*}{$\begin{array}{l}\text { Corporate governance } \\
\text { of BOD }\end{array}$} & BLOOK & .093 & .586 & .563 & .081 & .584 & .564 & -.061 & -.386 & .702 & .068 & .538 & .595 & 1.473 \\
\hline & FORIGEN & .010 & .056 & .956 & -.225 & -1.484 & .149 & -.130 & -.749 & .460 & -.145 & -1.053 & .301 & 1.766 \\
\hline & INSTITU & -.024 & -.140 & .889 & .062 & .417 & .680 & .138 & .807 & .427 & .060 & .447 & .658 & 1.696 \\
\hline & DUALITY & -.020 & -.114 & .910 & -.249 & -1.597 & .121 & -.145 & -.812 & .424 & -.189 & -1.344 & .190 & 1.854 \\
\hline & B.INDIP & -.008 & -.048 & .962 & -.174 & -1.136 & .265 & -.197 & -1.125 & .270 & -.162 & -1.174 & .250 & 1.786 \\
\hline \multirow{3}{*}{$\begin{array}{c}\text { Corporate governance } \\
\text { of SSB }\end{array}$} & SSBSIZE & .288 & 1.841 & $.076^{*}$ & -.016 & -.114 & .910 & .159 & 1.021 & .316 & .261 & 2.122 & $.043^{*}$ & 1.417 \\
\hline & SSBREPU & .560 & 1.788 & $.085^{*}$ & .027 & .097 & .923 & .276 & .883 & .385 & .248 & 1.003 & .324 & 5.693 \\
\hline & SSBCROSS & .831 & 2.209 & $.035^{*}$ & .005 & .015 & .988 & -.240 & -.641 & .527 & .463 & 1.562 & .130 & 8.194 \\
\hline \multicolumn{2}{|c|}{$\begin{array}{c}\text { Model Summary: R Square } \\
\text { F-value } \\
\text { P-value }\end{array}$} & \multicolumn{3}{|c|}{$\begin{array}{l}2.142 \\
0.042\end{array}$} & \multicolumn{3}{|c|}{$\begin{array}{l}3.464 \\
0.002\end{array}$} & & $\begin{array}{l}0.518 \\
2.153 \\
0.041\end{array}$ & & & $\begin{array}{l}0.700 \\
4.663 \\
0.000\end{array}$ & & \\
\hline \multicolumn{15}{|c|}{ 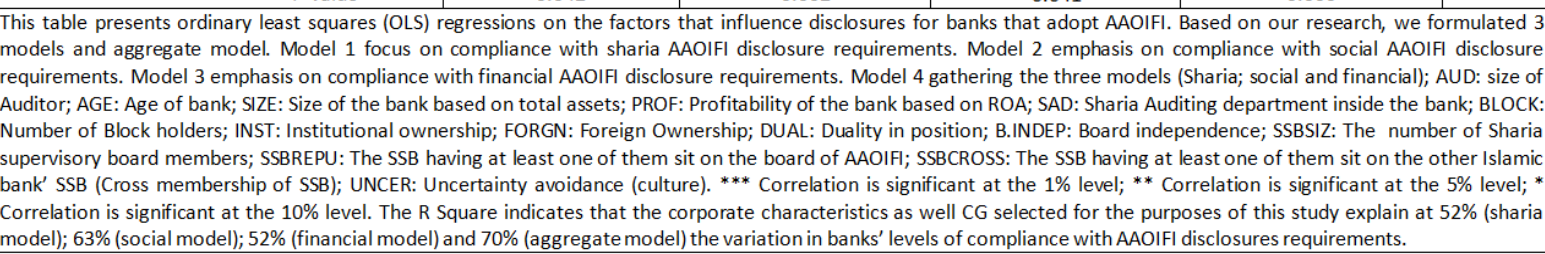 } \\
\hline
\end{tabular}

